\title{
Intra-individual numerical chromosomal polymorphism in Trichomycterus davisi (Siluriformes, Trichomycteridae) from the Iguaçu River basin in Brazil
}

\author{
Luciana Andreia Borin and Isabel Cristina Martins-Santos
}

\begin{abstract} size, followed by centric fission, which originated in this individual.

\section{INTRODUCTION}

The best known example of polymorphism in fish involving chromosomal rearrangement occurs among certain genera of the Salmonidae family. Both inter- and intra-individual chromosomal polymorphisms seem to be more extensive in rainbow trout than in other fish species (Thorgaard, 1976; Hartley and Horne, 1982). Intra-individual chromosomal variation in fish has been little studied. Most research concerning this type of variation refers to size and number differences in nucleolus organizer regions (Almeida-Toledo and Foresti, 1985) or to the presence of supernumerary chromosomes (Fenocchio and Bertollo, 1990). We examined a mosaic individual of Trichomycterus davisi with three cell populations. This polymorphism was attributed to postzygotic non-disjunction followed by centric fission.
\end{abstract}

Cytogenetic analysis of Trichomycterus davisi, collected from the Iguaçu River basin, has shown a diploid number of $2 \mathrm{n}=54$ chromosomes. However, we observed intra-individual numerical polymorphism in a T. davisi specimen. There were three cell populations with diploid number $2 \mathrm{n}=54(40 \mathrm{M}+12 \mathrm{SM}+2 \mathrm{ST}), 2 \mathrm{n}=55(40 \mathrm{M}+12 \mathrm{SM}+2 \mathrm{ST}+1 \mathrm{M})$ and $2 \mathrm{n}=56(40 \mathrm{M}+12 \mathrm{SM}+2 \mathrm{ST}+2 \mathrm{~A})$ chromosomes. This variation was attributed to a probable post-zygotic non-disjunction of a metacentric chromosome of small/middle

\section{MATERIAL AND METHODS}

Cytogenetic analyses of 50 individuals (20 males and 30 females) of the species Trichomycterus davisi were perfomed. Among specimens collected in Três Barras do Paraná, PR, Brazil (Iguaçu River basin) one had intra-individual polymorphism and was be analyzed in the present study. Mitotic chromosomes were obtained according to the air-drying technique described by Bertollo et al. (1978). Chromosomes were classified according to Levan et al. (1964).

\section{RESULTS AND DISCUSSION}

Previous karyotypic analyses of $T$. davisi indicated a diploid number of $2 \mathrm{n}=54$ chromosomes and a karyo- typic formula of 40M, 12SM and 2ST (Borin and Martins-Santos, 1999). However, one specimen had three populations of different cells. Analysis of 42 metaphases showed three cytotypes consisting of 18 cells with normal karyotype $(2 \mathrm{n}=54,40 \mathrm{M}+12 \mathrm{SM}+2 \mathrm{ST}$; Figure 1a), two with 55 chromosomes $(40 \mathrm{M}+12 \mathrm{SM}+$ $2 \mathrm{ST}+1 \mathrm{M}$; Figure $1 \mathrm{~b}$ ), due to the presence of one medium-sized metacentric chromosome, and 19 cells with 56 chromosomes $(40 \mathrm{M}+12 \mathrm{SM}+2 \mathrm{ST}+2 \mathrm{~A}$; Figure $1 \mathrm{c})$, due to the presence of two acrocentric chromosomes. Furthermore, cells with 53 chromosomes were detected (Figure 2), although absent chromosome could not to determined. Cell populations with 55 chromosomes may have originated due to a post-zygotic nondisjunction of a medium-sized metacentric chromosome and $2 \mathrm{n}=56$ chromosome cells by chromosome fission in the first divisions after non-disjunction. The latter event would originate cells with two acrocentric chromosomes. A similar mosaic in an individual of Trichomycterus sp. (equal T. paolence), collected from Quinta brook (Itatinga, SP) was registered by Torres et al. (1995). Four different cytotypes were observed in this specimen: $2 \mathrm{n}=54$ (normal karyotype), $2 \mathrm{n}=55(2 \mathrm{n}=$ $54,+1$ submetacentric $), 2 n=55(2 n=54,+1$ small metacentric) and $2 n=56(2 n=54,+2$ chromosomes, a submetacentric and a small metacentric). According to these authors, such results suggest and even characterize this specimen as a carrier of an aneuploidy due to post-zygotic non-disjunction events, that probably occurred during the first blastomere divisions. Arratia and Veloso (1980) also detected a variation of chromosome numbers in T. areolatus and T. laucaensis. 


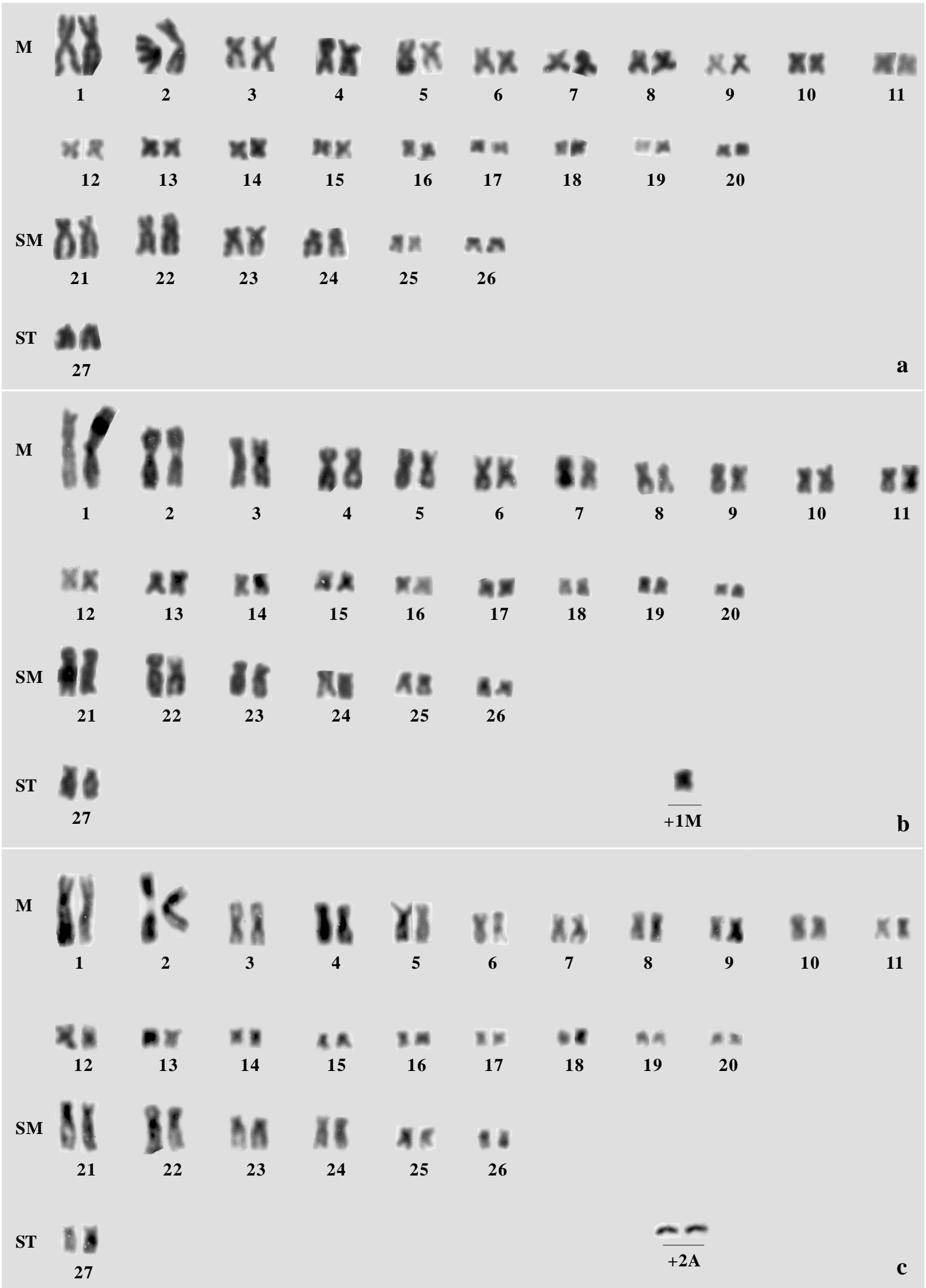

Figure 1a, b, c - Karyotype of Trichomycterus davisi with $2 n=54,55$ and 56, repectively. 


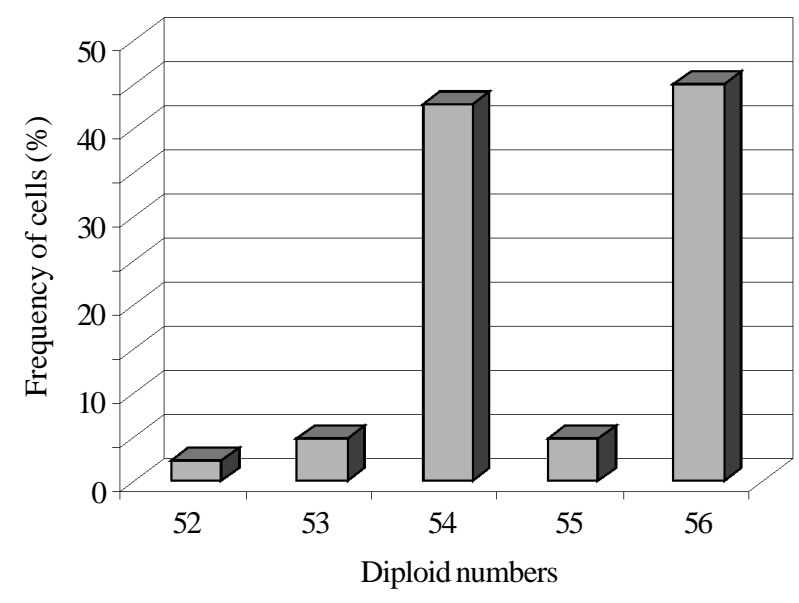

Figure 2 - Frequency of chromosome numbers in cells of the mosaic specimen of Trichomycterus davisi.

Ohno et al. (1965) mentioned cases of post-zygotic rearrangements in the rainbow trout Oncorhynchus mykiss. Chromosome number of this species varied from 58 to 65 and was found in seven different karyotypes with FN $=104$. They concluded that Robertsonian polymorphism occurred in each individual, with certain chromosome arms undergoing fusion and fission at the beginning of embryonic life. This would produce different somatic cells with different chromosome numbers.

Chromosomal alterations may occur either spontaneously, or chemical and physical agents may induce them. According to Julio Jr. et al. (1997) the Iguaçu River has been subjected to intense aggression during the last hundred years. Since its sources lie in a region with the highest population density in the State of Paraná, the river receives considerable urban and industrial effluent. This fact can be related to the appearance of the chromosomal variation found in this individual.

\section{ACKNOWLEDGMENTS}

The authors are thankful to CNPq for financial support; to NUPELIA for supplying the specimens analyzed and to Wolmar
Benjamin Wosiacki, M.Sc., of the Federal University of Paraná for making the species identification.

\section{RESUMO}

Análise citogenética de T. davisi, coletada na bacia do rio Iguaçu, demonstrou um número diplóide de $2 \mathrm{n}=54$ cromossomos. Contudo, um indivíduo desta espécie apresentou polimorfismo intra-individual numérico. Análise mitótica mostrou três populações de células com número diplóide de $2 \mathrm{n}=54(40 \mathrm{M}+12 \mathrm{SM}+$ $2 \mathrm{ST}), 2 \mathrm{n}=55(40 \mathrm{M}+12 \mathrm{SM}+2 \mathrm{SM}+1 \mathrm{M})$ e $2 \mathrm{n}=56(40 \mathrm{M}+$ $12 \mathrm{SM}+2 \mathrm{SM}+2 \mathrm{~A}$ ) cromossomos. Esta variação foi atribuída a uma provável não disjunção pós-zigótica de um cromossomo metacêntrico de tamanho médio/pequeno, seguido de fissão cêntrica, originando um indivíduo mosaico.

\section{REFERENCES}

Almeida-Toledo, L.F. and Foresti, F. (1985). As regiões organizadoras do nucléolo em peixes. Ciênc. Cult. 37: 448-453.

Arratia, G. and Veloso, A. (1980). Cariotipos de peces Trichomicterideos (Siluriformes) Arch. Biol. Med. Exp. 13: 137 (Abstract).

Bertollo, L.A.C., Takahashi, C.S. and Moreira Filho, O. (1978). Cytotaxonomic considerations on Hoplias lacerdae (Pisces, Erythrinidae). Rev. Bras. Genet. I: 103-120.

Borin, L.A. and Martins-Santos, I.C. (1999). Karyotype characterization of three species of genus Trichomycterus (Teleostei, Siluriformes) from Iguaçu River basin. Genetica 106: 215-221.

Fenocchio, A.S. and Bertollo, L.A.C. (1990). Supernumerary chromosomes in a Rhamdia hilari population (Pisces, Pimelodidae). Genetica 81: 193-198.

Hartley, S.E. and Horne, M.T. (1982). Chromosome polymorphism in the rainbow trout (Salmo gairdneri) Richardson. Chromosoma 87: 461-468

Julio Jr., H.F., Bonecker, C.C. and Agostinho, A.A. (1997). Reservatório de Segredo e sua inserção na bacia do rio Iguaçu. In: Reservatório de Segredo - Bases Ecológicas para o Manejo (Agostinho, A.A. and Gomes, L.C., eds.). EDUEM, Maringá, pp. 61-84.

Levan, A. Fredga, K. and Sandberg, A.A. (1964). Nomenclature for centromeric position on chromosomes. Hereditas 52: 201-220.

Ohno, S., Stenius, C., Faissit, E. and Zenzes, M.T. (1965). Post-zygotic chromosomal rearrangements in rainbow trout (Salmo irideus Gibbons). Cytogenet. 4: 117-129.

Thorgaard, G.H. (1976). Robertsonian polymorphism and constitutive heterochromatin distribution in chromosomes of the rainbow trout (Salmo gairdneri). Cytogenet. Cell. Genet. 17: 174-184.

Torres, R.A., Foresti, F. and Oliveira, C. (1995). Ocorrência de mosaicismo cariotípico em Trichomycterus sp. (Pisces, Siluriformes, Trichomycteridae). Rev. Bras. Genet. 18 (Suppl.): 470.

(Received December 9, 1999) 
